\title{
Comparative Comparison of Effectiveness of Two Methods of SMS and TV Advertising on The Reputation and Brand Attitude (Case Study: Goldiran Company)
}

\author{
Bahareh Hanjani and Ali Akhavan* \\ Department of Industrial Management, Naragh Branch, Islamic Azad University, Iran \\ bahare.hanjani1363@gmail.com \\ * Correspondence: aakhavan@iau-naragh.ac.ir
}

\begin{abstract}
Given the varying impact of promotional methods, brand development can help to creating consumer acceptance of a new product through a new product linkage with a well-known brand or company name, but an inappropriate brand development can create distorted associations that may it is difficult for companies to overcome them. The purpose of this research is to Comparative comparison of effectiveness of two methods of SMS and TV advertising on the reputation and brand attitude in Goldiran Company which sampled a sample of 384 Goldiran products customers who were exposed to both television and SMS and then returned to the store. The present research is based on the method and nature of descriptive work of the field type as well as in terms of purpose, it is applicable and in terms of time, it is timeconsuming. For gathering information used from two methods, library and field. A library method was used to formulate theoretical bases of the research, research background and design of the conceptual model. The field method was used to collect the data by using a questionnaire. In the present research, the methods used in descriptive statistics such as absolute frequency distribution tables, average and the Kolmogorov-Smirnov test was used to assess the normal status of the sample and compare the data collected through a questionnaire. In the inferential statistics section was used from the comparison test of the average of the two societies and the comparison test of the average of several societies. After testing the hypothesis, all the research hypotheses were accepted therefore, it can be said that there is a significant difference between the effect of SMS and TV advertising on reputation and brand attitude at Goldiran Company.
\end{abstract}

Keywords: SMS and television advertising, brand reputation, brand attitude, customer pleasure, customer confidence. 


\section{Introduction}

Brand creates identities for products and services and distinguishes them from rival products. One of the most valuable assets of any company is the intangible asset which is provided by the company's brand. So, since the initial capital of many businesses is their brand (Keshvarshahi and Rastegar, 2010) and the brand maximizes the value of the company -the company's special value -, brand management is an important category (Clare, 2010: 21). But the problem is that new messages and practices are not accepted at the same time by the people of the community. The truth of this is to a degree that can be said even when all people are aware of a new message or new phenomenon at a time and to a certain extent, there is still no consistency, harmony and uniformity in terms of action, there are those who receive the message faster than others and use. Some people expect to see the results of the practical experience of others, and so that nobody or those in the new way will follow, they will never step in this new way. However, the issue of commercial advertising in Iran has always been viewed as a social concern by audiences. Social researchers often look at it with a critical approach. But propaganda, has been less well received by the researchers in terms of theoretical and practical studies of pathology. Few existing studies have not examined the impact of advertising methods on brand dimensions, such as attitude and brand personality. Given the varying impact of promotional methods, brand development contributes to creating consumer acceptance of a new product through a new product linkage with a well-known brand or company name, but an inappropriate brand development can create distorted associations that it is difficult for companies to overcome them. The purpose of this research is to Comparative comparison of effectiveness of two methods of SMS and TV advertising on the reputation and brand attitude in Goldiran Company 


\section{Research overview}

\section{1-1. The importance of necessity of research}

Rapid changes in today's world have led organizations to face a number of challenges, but organizations are successful that use the opportunities created to benefit from them with the help of modern management tools and technologies. Today's world of trade is in an era of forefront, an era which strong international brands have come into various areas, and the survival of large companies has been threatened by rivals. In order to deal with this issue, the renowned global companies should assess their current position and how consumers perceive it, seek to maintain and strengthen their position and promote consumers' awareness of their brand (Abdollah Baki, 2014: 7). In examining the importance of brand reputation, since the goal of customer relationship management is to establish long-term relationships with them, developing and maintaining of brand reputation is one of the ways to achieve this goal. The brand reputation that can be formed through marketing, sales promotion, and organizational social responsibility can not be created at all but when it comes into existence, it will have a long lifetime and can lead to a reduction in the cost of promotional activities and scale savings for the company. Therefore, the necessity of developing and acquiring efficient and effective marketing methods is essential for creating and placing the brand personality of appropriate for institutions (Motameni et al., 2010: 3).

On the other hand, the importance of brand attitudes can also be explained that customers have found natural the relationships with brands and described them with various personality features such as honest, cheerful, cheating, or strong. (Martinez et al., 2009: 306). A strong brand allows company to make more distinct operations than competitors and add to itself brand values and reputation (Racio \& Leon, 2007: 384).

For organizations, the importance of examining the brand's attitude and reputation is that it can easily and with more rapidly and with scientific methods, to attract serious customers and maintain its previous customers and its products and services are optimally introduced to customers. On the other hand, researchers who in the future want to work on this method know which types of advertising should do more research. Another important of this study is to get a clear picture from how direct influence of research variables on brand reputation and attitude that can be useful for future decision makers and other stakeholders. 


\section{Theoretical bases.}

\section{2-1- Research history}

\section{2-1-1- Research internal history}

- Mehrdad Hassanzadeh (2015) conducted a research entitled "Investigating and Prioritizing the Factors Affecting on the Brand Reputation (Case Study: Mahram Brand)".Brand is one of the most valuable assets of any organization that its proper management can pave the way for more market share and more profitability in any industry. In this regard, brand reputation is one of the most important issues of marketing and brand domain, accordingly, the present research was conducted with the aim of investigating the effect of to be uniqueness of good, creativity and choice of advertising message, choice of media type and doing of market research on its reputation in the food industry (food products of Mahram).

- Abbas Ziaeekia (2015) conducted a research on "The impact of quality, price, reputation and advertising on customers' perceptions on brand choices on Zar Macaron products" and expressed this point that brand rank among all existing competitors has a significant impact on customer perceptions. Whatever the brand position is higher in the market, the customers feel more confident about it. The findings of the research showed that quality, reputation, price and advertising are effective on the perception of customers in selecting a brand.

\section{2-1-2- Research foreign history}

- Hater et al. (2014) examined the impact of user interactions in social media on brand awareness and intent to buy. The brand commitment has a positive and significant effect on brand awareness, mouth-tomouth advertising and purchase intention. Annoyance has a negative and significant effect on brand commitment and oral-to-mouth advertising, but it does not affect brand awareness and intent to purchase. Awareness of the brand has a positive and significant effect on mouth-to-mouth advertising. The effect of mouth-to-mouth advertising on purchase intention was not significant. 
- Verays et al. (2012) examined the reputation and credibility of brand in brand affiliate pages: A survey of the impact of social media marketing on them.

\section{2-2- Research objectives}

\section{2-2-1- Main objective}

1. Determine the difference of impact of SMS and TV advertising on brand reputation in Goldiran Corporation.

2. Determine the difference of impact of SMS and TV advertising on brand attitude in Goldiran Corporation.

\section{2-2-2- Minor objectives}

1. Determine the difference of impact of SMS and TV advertising on brand benefit in Goldiran Corporation.

2. Determine the difference of impact of SMS and TV advertising on customer pleasure in Goldiran Corporation.

3. Determine the difference of impact of SMS and TV advertising on perceived Customer Value in Goldiran Corporation.

4. Determine the difference of impact of SMS and TV advertising on customer satisfaction in Goldiran Corporation.

5. Determine the difference of impact of SMS and TV advertising on customer confidence in Goldiran Corporation.

\section{Research Method}

Considering that the purpose of this research is to use its results to use optimal advertising methods to increase brand reputation and improve customer's attitude towards its in Goldiran Company, in terms of purpose, it is applicable and given the fact that this research is done within a certain time limits, in terms of time, it is time-consuming. 


\section{Data Analysis}

\section{4-1. Descriptive statistics analysis}

Based on the information obtained from the statistical samples, the status of the demographic variables is as follows table:

\begin{tabular}{|c|c|c|c|}
\hline percent & abundance & & \\
\hline 18 & 68 & diploma & \multirow{5}{*}{$\begin{array}{l}\text { level of } \\
\text { education }\end{array}$} \\
\hline 23 & 88 & associates degree & \\
\hline 34 & \multirow{2}{*}{$\begin{array}{c}131 \\
97\end{array}$} & bachelor's degree & \\
\hline 25 & & $\begin{array}{l}\text { master's degreeand } \\
\text { and higher }\end{array}$ & \\
\hline 100 & 384 & sum & \\
\hline 64 & 252 & female & \multirow[t]{3}{*}{ gender } \\
\hline 34 & 132 & male & \\
\hline 100 & 384 & sum & \\
\hline 3 & 11 & less than 30 & \multirow[t]{5}{*}{ age } \\
\hline 21 & 80 & 30 to 40 & \\
\hline 36 & 140 & 40 to 50 & \\
\hline 40 & 153 & 50 & \\
\hline 100 & 384 & sum & \\
\hline 24 & 93 & single & \multirow{3}{*}{$\begin{array}{c}\text { marital } \\
\text { status }\end{array}$} \\
\hline 76 & 291 & married & \\
\hline 100 & 384 & sum & \\
\hline
\end{tabular}

\section{4-2. Inferential statistics}

\section{4-2-1. normalization}

In order to be able to average the responses to each of variables of the usefulness, enjoyment, perceived value, satisfaction and trust of the customer in the two SMS and TV advertising groups that to compare them with comparative tests, we defined the variables including the mean Individual responses to questions from each component are in both television and sms advertising groups. We will use these variables to examine the research hypothesis. 
Table 1. Kolmogorov-Smirnov test

\begin{tabular}{|c|c|c|c|c|}
\hline $\begin{array}{c}\text { data distribution } \\
\text { status }\end{array}$ & significant (sig) & statistics Z & variable & Row \\
\hline abnormal & 0.000 & 2.702 & brand benefit & 1 \\
\hline abnormal & 0.000 & 3.416 & customer pleasure & 2 \\
\hline abnormal & 0.003 & 1.820 & perceived customer value & 3 \\
\hline abnormal & 0.000 & 3.757 & customer satisfaction & 4 \\
\hline abnormal & 0.000 & 3.247 & customer confidence & 5 \\
\hline abnormal & 0.000 & 2.779 & brand reputation & 6 \\
\hline abnormal & 0.006 & 1.693 & brand attitude & 7 \\
\hline
\end{tabular}

\section{4-2-2- First minor hypothesis}

"There is a significant difference between the impact of SMS and TV advertising on the brand's benefit in Gladiran company."

Table 2. Result of the first hypothesis review

\begin{tabular}{|c|c|c|}
\hline \multicolumn{3}{|c|}{$\begin{array}{l}\text { The results of the Man-Whitney test for comparison of brand benefit in } \\
\text { both the SMS and television advertising groups }\end{array}$} \\
\hline \multicolumn{2}{|c|}{0.235} & test sig value \\
\hline TV Advertising & SMS Advertising & Classification \\
\hline 384 & 384 & Number \\
\hline 359.27 & 377.73 & Average Ratings \\
\hline
\end{tabular}

Considering that in this test sig value is more than $5 \%$ and equals 0.235 , so the average benefit is equal in two groups of SMS and TV advertising. 


\section{4-2-3- Second minor hypothesis}

"There is a significant difference between the impact of SMS and TV advertising on the customer pleasure in Gladiran company."

Table 3. Result of the second hypothesis review

\begin{tabular}{|c|c|c|}
\hline \multicolumn{3}{|c|}{$\begin{array}{c}\text { The results of the Man-Whitney test for comparison of customer } \\
\text { pleasure in both the SMS and television advertising groups }\end{array}$} \\
\hline \multicolumn{2}{|c|}{0.235} & test sig value \\
\hline TV Advertising & SMS Advertising & Classification \\
\hline 384 & 384 & Number \\
\hline 324.70 & 412.30 & Average Ratings \\
\hline
\end{tabular}

Considering that in this test sig value is more than $5 \%$ and equals 0.000 , so the average customer pleasure is not equal in two groups of SMS and TV advertising. As the average rankings show, customer pleasure is more and higher in SMS advertising.

\section{4-2-4- Third minor hypothesis}

"There is a significant difference between the impact of SMS and TV advertising on the perceived customer value in Gladiran company."

Table 4. Result of the third hypothesis review

\begin{tabular}{|c|c|c|}
\hline \multicolumn{3}{|c|}{$\begin{array}{l}\text { The results of the Man-Whitney test for comparison of perceived } \\
\text { customer value in both the SMS and television advertising group }\end{array}$} \\
\hline \multicolumn{2}{|c|}{0.235} & test sig value \\
\hline TV Advertising & SMS Advertising & Classification \\
\hline 384 & 384 & Number \\
\hline 302.02 & 434.98 & Average Rating \\
\hline
\end{tabular}


Considering that in this test sig value is more than $5 \%$ and equals 0.000 , so the average perceived customer value is not equal in two groups of SMS and TV advertising.

\section{4-2-5- Fourth minor hypothesis}

"There is a significant difference between the impact of SMS and TV advertising on the customer satisfaction in Gladiran company."

Table 5. Result of the fourth hypothesis review

\begin{tabular}{|c|c|c|}
\hline \multicolumn{3}{|c|}{$\begin{array}{c}\text { The results of the Man-Whitney test for comparison of customer } \\
\text { satisfaction in both the SMS and television advertising groups }\end{array}$} \\
\hline \multicolumn{2}{|c|}{0.235} & test sig value \\
\hline TV Advertising & SMS Advertising & Classification \\
\hline 384 & 384 & Number \\
\hline 386.67 & 350.33 & Average Ratings \\
\hline
\end{tabular}

Considering that in this test sig value is more than $5 \%$ and equals 0.019 , so the average customer satisfaction is not equal in two groups of SMS and TV advertising.

\section{4-2-6- Fifth minor hypothesis}

"There is a significant difference between the impact of SMS and TV advertising on the customer confidence in Gladiran company."

Table 6. Result of the fifth hypothesis review

\begin{tabular}{|c|c|c|}
\hline \multicolumn{3}{|c|}{$\begin{array}{l}\text { The results of the Man-Whitney test for comparison of customer } \\
\text { confidence in both the SMS and television advertising groups }\end{array}$} \\
\hline \multicolumn{2}{|c|}{0.235} & test sig value \\
\hline TV Advertising & SMS Advertising & Classification \\
\hline 384 & 384 & Number \\
\hline 337.62 & 399.38 & Average Ratings \\
\hline
\end{tabular}


Considering that in this test sig value is more than $5 \%$ and equals 0.000 , so the average customer confidence is not equal in two groups of SMS and TV advertising.

\section{4-2-7- Main hypotheses}

Table 7. Result of the main hypothesis review

\begin{tabular}{|c|c|c|}
\hline \multicolumn{3}{|c|}{$\begin{array}{l}\text { The results of the Man-Whitney test for comparison of brand reputation and } \\
\text { attitude in both the SMS and television advertising groups }\end{array}$} \\
\hline \multicolumn{2}{|c|}{0.000} & test sig value in brand reputation \\
\hline \multicolumn{2}{|c|}{0.000} & test sig value in brand attitude \\
\hline TV Advertising & SMS Advertising & Classification \\
\hline 384 & 384 & Number \\
\hline 333.70 & 403.30 & Average Ratings in brand reputation \\
\hline 326.39 & 410.61 & Average Ratings in brand attitude \\
\hline
\end{tabular}

Considering that in this test sig value is more than $5 \%$ and equals 0.000 , so the average brand reputation and attitude is not equal in two groups of SMS and TV advertising. 


\section{Research results}

\section{A) Review the impact of SMS and TV advertising on brand reputation}

In comparison results of this research with research of Parhizgar et al. (2012), he concluded that there is no relationship between advertising and brand reputation. Also, Hadipour's research (2013) evaluated this relationship and the result showed that there is a significant relationship between advertising, customer perception and customer attitude with the acceptance of mobile banking, which is not related to this research. In the research of Azizi et al., the relationship between some dimensions of brand reputation with advertising has been proven. Behnam et al. (2015) also introduced mouth-tomouth advertising the factor to improve brand reputation. Sehhat et al. (2012). believe advertising agents such as the distribution severity, company promotion and price to be effective in brand reputation, respectively. Abbasi et al. (2011) also considered that commercial advertising is to be the most influential factor in increasing the value of a brand name. Mira and Karimi (2012) concluded that media and non-media advertisements has the most impact on brand equity, respectively. Doaee et al. considered that widespread advertising and timely distribution in stores would make the customer better understood the brand. Wang et al. (2002) considers television advertising influential on brand reputation. Yu and Lee (2000) considers the high advertising to increase brand value and reputation. Boyle et al. (2013) proved the advertising and promotion of sales and their impact on creating special value and brand reputation. Baldaf et al. (2009), Kim and Hyun (2011) also achieved similar results.

\section{B) Review the impact of SMS and TV advertising on brand attitudes}

Zarei et al. (2015) concluded that SMS advertising affects customers' attitudes. Motameni et al. express the direct impact of social engagement and ease of attitudes toward short message advertising. Hashemi (2014) also achieved similar results. Wang et al. (2002) considers TV advertising to be an influential on brand attitude. Hao et al. (2008) and Wang and Sun (2010) also achieved similar results. 


\section{C) Review the effect of demographic variables on brand reputation and attitude}

Baker and Palan (2010) concluded that gender affects on children's attitude toward products. Wang et al. (2002) considers television advertising to be an influential on brand reputation. Whaley et al. (2007) considers gender as a factor in students' beliefs and attitudes to buying costumes to be affect.

\section{5-1. Research suggestions}

A) Related suggestions with the impact of SMS and TV advertising on brand attitudes

- Using of creative advertising methods in television advertising

- Offer to buy goods and services by SMS for brand induction in the minds of customers

- Using of modern and different products and services and introducing them by teaser and SMS

- Be honest with customers

- Professional training of employees towards the client

- Make discount plans and announce it by SMS and TV

- Increasing work standards.

- Using of modern methods of distributing of goods and services, particularly at the place of residence and work

B) Related suggestions with the impact of SMS and TV advertising on brand reputation

- Increase the level of credibility of the organization through the adoption of work and management standards

- Optimization of the organization's physical conditions in order to induce optimization to customers

- Creating charm in the company's brand

- Performing multiple text and TV advertising to induce brand to customers

- No imitation of other brands and competitors

- Observe the principle of truthfulness to customers

- Attention to functional suggestions of employees and customers to improve the organization's performance

- Attention to plans and ideas of users of products and services of the organization

- Prepare and publicly available the basic needs of customers for better access to organization services such as Internet services 
- Periodic measurements of organizational performance and compliance with criteria

- Encourage successful staff at the organization level

- Encourage customers and gratitude them in the form of awards and designs

- Creating a system of criticisms and suggestionsat the organization level

- Facilitate customer access to managers to resolve issues and problems

- Review general meetings and discussions and exchange with employees

\section{References}

1. Abbasi A., Mohammadian M. (2007). The Relationship between Consumer Attitudes to Websites and Internet Advertising Effectiveness, Journal of Management Sciences of Iran, Second Year, No. 7, Pages 99-119.

2. Bakyr and saddle (2010) in a study on how children view the promotions and products affected by the concept of gender in advertising. The Journal of Product and Brand Management, 17, 252-263.

3. Baldauf, A., Cravens, K., Diamantopoulos, A., \& Zeugner , R. (2009). The impact of product-Baldauf A, Cravens KS, Diamantopoulos A, Zeugner-Roth KP. The impact of product-country image and marketing efforts on retailer-

4. Behnam et al. (2015). Investigating the effect of mouth-to-mouth advertising on the creation of a value of brand is based on the consumer. Sport Management Studies. No. 31, Pages 85-104

5. Buil , I., Martı'nez, E., \& Chernatony, L. (2013). The influence of brand equity on consumer responses. Journal of Consumer Marketing, 30, 62-74.

6. Hao et al (2008) in a study to evaluate the factors influencing customer purchase intent. journal of product \& brand management, 235-246.

7. Hashemi. (2014). The extent of the impact of the television advertising attractions of company of Irancell and mci on attitude toward brand name and attitude towards advertising, Commercial Management Publishing, Pages 36-25

8. Keller, Kevin, Lane, (2010). Strategic Brand Management, Bathhaie Interpreter Present, Aware of the Publication, First Published in Tehran in 2008. 
9. Kim, J.-H., \& Hyun, Y. J. (2011). A model to investigate the influence of marketing-mix efforts and corporate image on brand equity in the IT software sector. Industrial Marketing Management, 40, 424-438.

10. Mira S.A., Karimi Harrisi S. (2012). Investigating the Effect of Media and NonOfficial Advertising on the Value of the Brand Name (Case study: Pars Khazar brand), Commercial Management Publishing, No. 4, Pages 105-126.

11. Mutmani A., Moradi H. Hemati A. (2010). Impact of brand personality on customer loyalty, Cheshmandaz magazine, Commercial Management Publishing.

12. Parezgar, M.M., Ebrahim Abed M. (2012). Investigating the Impact of Brand Specific Dimensions in Acer Model on Brand value in Consumer Views (Case Study: Samsung Brand). Commercial Reviews, No. 53, Pages 61-71.

13. Raggio, R., \& Leone , R. (2007). The theoretical separation of brand equity and brand value:managerial implications for strategic planning. Journal of Brand Management, 14(5), 380-395.

14. Sehhat. Kashkouli (2012). Investigating the Effect of Marketing Mix on the value of the Trademark Name of the Karafarin Insurance Company. Commercial Management Publishing, No.12, Pages 71-90

15. Wang and Sun (2010) study examined the relationship between consumer beliefs about online advertising, attitudes toward online advertising. Journal of Business Research, 58(4), 364-379.

16. Wang et al (2002) study aimed to measure consumer attitudes toward advertising, for different purposes and different functions in the media, . International Review of Business Research Papers, 4, 245-260

17. Wiley, B. J., krisjanous, J., and Elisabeth, C. (2007). An experimental study of female tweener's evaluative beliefs regarding ads, attitude toward the ad, and purchase intent for fashion apparel. Young Consumer, 8.(2)

18. Yoo, B., Donthu , N., \& Lee, S. (2000). An Examination of Selected Marketing Mix Elements and Brand Equity. Journal of the Academy of Marketing Science, 195-211. 